JPdK Volume 2 No1 Tahun 2020 Halaman 72-75

JURNAL PENDIDIKAN dan KONSELING

Research \& Learning in Primary Education

\title{
Manfaat Bimbingan dan Konseling Bagi Siswa
}

\author{
Tika Evi \\ Program Studi Pendidikan Guru Sekolah Dasar \\ Fakultas Ilmu Pendidikan \\ Universitas Kristen Satya Wacana \\ Email: 292017120@student.uksw.edu
}

\begin{abstract}
Abstrak
Penelitian ini bertujuan untuk mengetahui manfaat bimbingan dan konseling bagi siswa SD. Penelitian ini menggunakan metode penelitian kepustakaan. Metode pengumpulan data yang digunakan yaitu membaca buku-buku, makalah atau artikel, majalah, jurnal, web (internet). Analisis data yang digunakan yaituanalisis Interaktif. Hasil penelitian ini untuk mengetahui : 1) Pengertian bimbingan dan konseling, 2) tujuan dari bimbingan dan konseling, 3) peran konselor dalam konseling, 4) pengertian pendidikan Sekolah Dasar, 5) pentingnya bimbingan dan konseling di Sekolah Dasar, 6) Prosedur pelaksanaan konseling
\end{abstract}

Kata Kunci : Manfaat Bimbingan dan Konseling Bagi Siswa SD

\section{PENDAHULUAN}

Salah satu indikator suatu bangsa dapat di lihat dari perilaku setiap individu yang ada dalam bagsa itu sendiri. Untuk menciptakan perilaku yang baik pada setiap orang maka dibutuhkan pendidikan yang bekualitaas. Pendidikan yang berkualitas di dukung oleh perkembangan kemampuan itu sendiri. Agar kemampuan yang dimiliki oleh setiap individu dapat berkembang dengan baik maka diperlukan lingkungan yang dapat membantu seseorang ersebut. Salah satunya adalah lingkungan sekolah. Sekolah adalah suatu lembaga yang digunakan untuk belajar dan pembentukan karakter siswa, baik sebagai individu atau anggota masyarakat.

Di sekolah guru huga memberikan layanan bimbingan dan konseling dengan tujuan agar dapat membantu peserta didik dalam membentuk dan mengembangkan potensi dan karakter yang dimiliki oleh setiap siswa. Layanan bimbingan dan konseling diberikan pada sekolah bak di SMA(Sekolah Menengah Atas) SMP(Sekolah Menengah pertama) mapun di SD (sekolah dasar).
Seiring dengan perkembangan zaman, permasalahan yang dihadapi peserta diidk sangat beragam, khususnya masalah yang di hadapi oleh siswa sd (sekolah dasar). Pada saat ini banyak perilaku siswa siswa sd yang dapat menghambat perkembangan potensi maupun dalam pembentukan karakter siswa. Peserta didik pada siswa sd (sekolah dasar) sering mengalami hambatan dan permasalahan yang belum bisa diselesiakan sendiri dan membutuhkan bantuan orang lain, terutama bantuan dari orang tua dan guru kelasnya. Saat ini banyak fenomena masalah yang terjadi pada siswa sd mulai dari kekerasan seksual, tawuran, merokok, bullying dan lain sebagainya. Baik sebagai pelaku maupun korban. Dalam permasalahan yang dihadapi oleh siswa guru kelas tidak dapat bergerak sendiri untuk membantu siswa dalam menyelesaikan masalah tersebut. Guru juga memerlukan orang yang ahli dalam bimbingan dan konseling. Oleh karena itu bimbingan dan konseling merupakan suatu komponen yang sangat penting dan harus ada di sekolahan khususnya sd agar dapat membantu guru kelas dalam menyelesaikan masalah-masalah yang dihadapi oleh siswa dan dapat membantu membentuk karakter yang baik pada siswa. 


\section{METODOLOGI PENELITIAN}

Metode yang digunakan dalam penelitian ini yaitu metode penelitiaan kepustakaan. Studi kepustakaan adalah suatu studi yang digunakan untuk mengumpulkan informasi dan data dengan bantuan dari berbagai macam material yang ada di perpustakaan seperti buku, majalah, dokumen, dsb.

\section{HASIL PENELITIAN DAN PEMBAHASAN}

\section{A. Pengertian Bimbingan dan Konseling}

Bimbingan adalah suatu proses pemberian bantuan yang dilakukan oleh orang ahli kepada seorang individu atau kelompok dengan tujuan agar setiap individu tersebut dapat memahami dirinya sendiri, mengenal lingkungan dan merencanakan masa depannya. Bimbingan diberikan untuk mengatasi berbagai persoalan atau kesulitan yang dihadapi oleh individu.

Konseling adalah hubungan antara dua orang yaitu konselor dengan klien, yang bertujuan untuk memberi bantuan untuk menyelesaikann masalah yang dihadapi oleh klien.

Dengan demikian dapat disimpulkan bahwa bimbingan dan konseling adalah suatu layanan bantuan yang dilakukan seorang konselor kepada klien atau peserta didik, agar klien dapat memahami dirinya sendiri, mengambil keputusan, memahami potensi yang dimilikinya, mengetahui cara mengembangkan potensi yang dimilikinya itu serta selalu bertanggung jawab atas setiap keputusan yang diambilnya.

B. Tujuan dari bimbingan dan konseling

Tujuan dari bimbingan dan konseling yaitu untuk:

a. Membantu setiap individu dalam mengembangkan diri secara optimal dan sesuai dengan tahap perkembangan

b. Mengatasi kesulitan yang dihadapi dalam studi

c. Serta dapat menyesuaikan diri sesuai dengan tuntutan positif dari lingkungan tempat tinggalnya.

C. Peran konselor dalam konseling
Konselor berperan sebagai patner klien dalam memecahkan atau mengatasi masalah yang dihadapi oleh klien. Konselor memberikan kesempatan pada klien untuk mengungkapkan atau menceritakan segala permasalahan yang dialaminya.

\section{Pengertian Pendidikan Sekolah Dasar}

Pendidikan sekolah dasar adalah suatu kegiatan pendidkan yang diperoleh oleh seseorang yang dilaksanakan secara teratur, sistematis, dan terarah. Diselenggarakan oleh lembaga pendidikan dengan menyelenggarakan program pendidkan enam tahun bagi anak di usia 6-12 tahun dari kelas satu smapai kelas enam, dan segala aktivitasnya sudah direncanakan atau dirancang yang sekarang disebut kurikulum.

E. Pentingnya bimbingan dan konseling di sekolah dasar

Bimbingan dan konseling harus di lakukan secara optimal di Sekolah dasar agar siswa mendapatkan pelayanan atau bantuan. Suatu layanan pemberian bantuan dikakuan oleh konselor kepada seorang klien atau peserta didik dengan tujuan agar klien dapat memahami dirinya sendiri, dapat membuat keputusan, memahami potensi atau kemampuan yang dimilikinya, mengetahui cara mengembangkan potensi tersebut, serta dapat bertanggung jawab atas setiap keputusan yang diambilnya. Bantuan semacam ini sangat tepat jka diberikan kepada siswa yang masih duduk di bangku sekolah dasar supaya setiap siswa bisa berkembang ke arah yang positif.

F. Prosedur pelaksanaan konseling individu

Proses konseling dibagi menjadi 3 tahap, yaitu sebagai berikut:

1. Tahap awal konseling atau tahap defenisi

Ditahap ini konselor bersama klien mendefinisikan masalah yang dialami oleh klien.

2. Tahap pertengahan konseling atau tahap inti

Ditahap ini konselor dan klien mengerjakan masalah yang dialami oleh klien. Pada tahap ini Teknikteknik konseling yang dilakukan yaitu: 

a. Memimpin
b. Memfokuskan
c. Konfrontasi
d. Mendorong
e. Menginformasikan
f. Pemberian nasehat
g. Menyimpulkan
h. Bertanya secara terbuka

3. Tahap akhir konseling atau tahap tindakan

Ditahap ini klien menciptakan tndakan-tindakan positif seperti perbuahan perilaku dan emosi, perencanaan hidup dimasa depan serta dapat mengatasi masalahnya sendiri.

Teknik konseling yang ada pada tahap ini yaitu:

\section{SIMPULAN}

Berdasakan hasil pembahasaan tentang manfaat bimbingan dan konseling bagi siswa SD dapat disimpulkan bawa bimbingan dan konseling sangat diperlukan di Sekolah Dasar agar peserta didik mendapatkan layanan bimbingan dan konseling dengan tujuan agar peserta didik atau klien, dapat merencanakan. hidup yang lebih baik dimasa yang akan

\section{DAFTAR PUSTAKA}

Adriani, Melisa. 2013. Kerjasama Guru Bimbingan Dan Konseling Dengan Guru Mata Pelajaran Dalam Mengembangkan Cara Belajar Siswa. Jurnal Ilmiah Konseling. Vol. 2, No. 1.

Aminah, Mungin. Dan Mungin. 2014. Pengembangan Model Program Bimbingan Dan Konseling Berbasis Karakter Di Sekolah Dasar.Jurnal Bimbingan Konseling

Gunawan, Ronny. 2018. Peran Tata Kelola Layanan Bimbingan dan Konseling Bagi Siswa di Sekolah. Jurnal Selaras Kajian Bimbingan dan Konseling Serta Psikologi Pendidikan. Vol. 1, No. 1

Kasih, Fitiria. 2017. Model Pengembangan Layanan Bimbingan Dan Konseling Dalam Membentuk Tingkah Laku
a. Menyimpulkan
b. Memimpin
c. Merencanakan
d. Mengevaluasi

Pada tahap akhir ini ditandai dengan beberapa hal diantaranya, yaitu:
a. Menurunya kecemasan klien
b. Adanya perubahan perilaku klien dari arah negatif ke arah positif, sehat dan dinamis
c. Adanya pemahaman baru dari klien terhadap masalah yang dihadapinya
d. Adanya rencana hidup di masa yang akan datang dengan program yang jelas dan positif

datang dapat memahami diri sendiri, mengetahui potensi yang dimilikinya, mengetahui cara mengembnagkan potensi yang dimilikinya, dapat mengambil keputusan, bertanggung jawab atas keputusan yang diambil, dan dapat mengikuti perkembangan yang ada dilingkungannya secara positif.

Remaja Bagi Orang Tua Tipe Permisif. Jurnal Counseling Care. Vol. 1, No. 1.

Nurohman, Agus. 2019 .Pentingnya Bimbingan Dan Konseling Di Sekolah Dasar (SD). Jurnal Bimbingan Dan Konseling

Nisa, Alfiatin. 2018. Analisis Kenakalan Siswa Dan Impliksinya Terhadap Layanan Bimbingan Konseling. Jurnal Bimbingan Konseling . Vol. 4, No.2.

Permana, Eko J. 2015. Pelaksanaan Layanan Bimbingan Dan Konseling Di Madrasha Aliyah Negeri 2 Banjarnegara. Jurnal Bimbingan Dan Konseling. Vol. 4, No. 2

Setiawan, Andi. dan Heru. 2019 . Peran Konselor Dalam Penanggulangan Pergaulan Bebas Dikalangan Remaja. Jurnal Bimbingan Dan Konseling. Vol 4, No. 2 
Tarjiah, Indina. 2015. Pengembangan Model Pembelajaran Matematika Bagi Siswa Berkualitas Belajar Di Sekolah Dasar Inklusi. Jurnal Ilmiah VISI PPTK PAUDNI. Vol. 10, No.2

Yaniswantoro, Dwi Tegar. Tanpa Tahun. Peran Konselor Untuk Membantu
Siswa Yang Mengalami Kesulitan Belajar Serta Bahasa Inggris di SMPN 2 Wlingi Kabupaten Blitar. Jurnal Penelitian Bimbingan Konseling. Vol. 1, No. 9. 